横行結腸癌術後に孤立性腹膜播種により胃結腸㾞を形成した 1 例

\begin{tabular}{|c|c|c|c|c|c|c|c|c|c|c|}
\hline & & & & & 点大 & 医科 & 研究所 & & & \\
\hline & 子 & & 聰 & 吉 崎 & & 嚴 & 秋 山 & 七千男 & 長谷部 & 浩 \\
\hline & 枝 & 好 & 幸 & 柳 衛 & 宏 & 宣 & 武 田 & 泰 隆 & 美 甘 & 晋 \\
\hline & 井 & 祐 & $\equiv$ & 江里口 & 正 & 純 & & & & \\
\hline
\end{tabular}

症例は72歳女性. 1985年 8 月横行結腸癌にて右半結腸切除術を受け，1988年 5 月孤立 性小腸転移によるイレウスのため回腸切除術を施行されている. 今回, 1993年10月筫血 と CEA 高值のため精查入院となった. 下部消化管内視鏡では, 異常所見は得られなかっ たが，上部消化管内視鏡では，胃大彎後壁に結腸に穿通する巨大漬瘍の形成を認めた。 胃癌の診断にて開腹し, 胃幽門側切除及び横行結腸合併切除を行った. 病理組織的には, 結腸癌の再発（孤立性腹膜播種）と診断された。結腸癌による胃結腸瘻の本邦報告例は, 18例あるが初発例のみであり, 自験例の様に孤立性小腸転移をきたした後に, 孤立性腹 膜播種再発により発症した症例の報告例は，文献的に認めない。

索引用語：横行結腸癌, 転移性小腸腫瘍, 胃結腸瘦

はじめに

結腸癌による胃結腸瘦の報告例は, 本邦では, 胃癌 によるものが多く，結腸癌によるものは比較的稀であ る.われわれは, 結腸癌術後, 3 年で孤立性小腸転移 をきたし,さらにその 5 年後, 胃結腸瘦にて発症した 結腸癌再発症例を経験したので若干の文献を加えて報 告する。

症例

患者：72歳，女性.

入院目的：貧血, CEA 高值の精查.

家族歴：特記すべきことなし.

既往歴：1985年 8 月 5 日に肝攀曲付近の横行結腸癌 に対して，右半結腸切除術を施行されている。術中所 見は H0P0N1（+）S2， stage III であった（図 1). 病理組織学的所見では $6.0 \times 8.5 \mathrm{~cm} 2$ 型結腸癌で, 中 分化型腺癌, ss, aw (-), ow (-), v(t), ly (+), nl (+) であった. その後外来にて follow up されて いたが、1988年 5 月, 腹痛出現し，イレウスの診断に て入院。保存的に観察していたが症状改善せず, 開腹 したところ, Treiz 勒帯より約 $2 \mathrm{~m}$ 肛門側の回腸に全周 性の狭窄を認め, 狭窄部位を切除し, 端々吻合を行っ た（図 2 ）。腹水を少量認めたが class I であった，肝

1994年 5 月18日受付 1994年 9 月13日採用

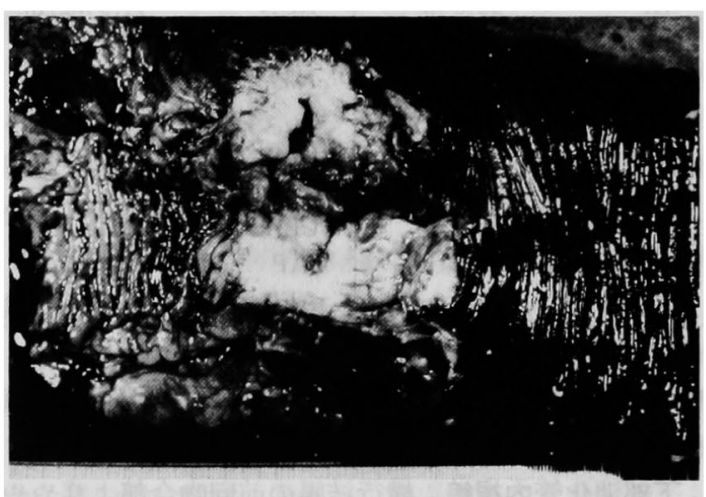

図 1 横行結腸切除標本 : $6.0 \times 8.5 \mathrm{~cm} 2$ 型のほほ全 周性の結腸癌を認める。

転移，腹膜播種を認めず，病理組織学的診断は前回結 腸癌と組織型を同じくする中分化型腺癌であり，転移 性によるものと判断された.

現病歴：上記以後,外来にて経過観察されていたが, 1992年12月頃より筫血が次第に進行し (Hb 7.9g/dl ま で隇少)，同年 8 月頃より CEA も徐々に上昇し始めた ため, 今回精査のため入院となった。特に自覚症状は なかった。

入院時現症: 身長 $144 \mathrm{~cm}$, 体重 $41 \mathrm{~kg}$, 眼瞼結膜に貧 血を認める以外特に異常所見を認めず。

入院時検査成績 (表 1$)$ ：負血 $(\mathrm{Hb} 7.9 \mathrm{~g} / \mathrm{dl})$ と総ビ 


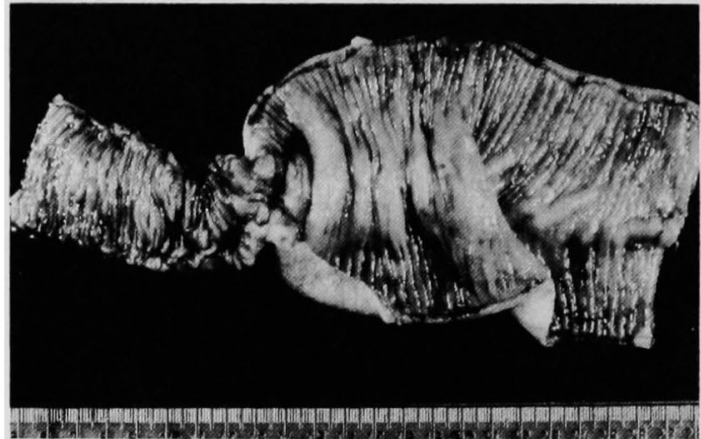

図 2 回腸切除標本：回腸は全周性に狭窄しており， 口側は拡張している，槳膜への浸潤は認められな かった.

表 1 入院時血液生化学検査

\begin{tabular}{|c|c|c|c|}
\hline $\begin{array}{l}\text { Stool } \\
\text { occult }\end{array}$ & $\operatorname{ood}(+)$ & $\begin{array}{l}\text { D.Bil } \\
\text { ALP }\end{array}$ & $\begin{array}{l}0.2 \mathrm{mg} / \mathrm{dl} \\
104 \mathrm{IU} / \mathrm{l}\end{array}$ \\
\hline \multicolumn{2}{|c|}{$\mathrm{CBC}$} & $\gamma$-GTP & $15 \mathrm{IU} / l$ \\
\hline WBC & $4,500 / \mu 1$ & GOT & $22 \mathrm{IU} / l$ \\
\hline $\mathrm{RBC}$ & $347 \times 10^{4} / \mu 1$ & GPT & $15 \mathrm{IU} / l$ \\
\hline $\mathrm{Hb}$ & $7.9 \mathrm{~g} / \mathrm{dl}$ & T.Chol & $172 \mathrm{mg} / \mathrm{dl}$ \\
\hline $\mathrm{Ht}$ & $26.9 \%$ & BUN & $11.9 \mathrm{mg} / \mathrm{dl}$ \\
\hline Plt & $24.1 \times 10^{4} / \mu l$ & $\mathrm{Cr}$ & $0.8 \mathrm{mg} / \mathrm{dl}$ \\
\hline \multicolumn{2}{|c|}{ Blood chemistry } & $\mathrm{Na}$ & $138 \mathrm{mEq} / \mathrm{l}$ \\
\hline $\mathrm{TP}$ & $6.0 \mathrm{~g} / \mathrm{dl}$ & K & $3.9 \mathrm{mEq} / l$ \\
\hline Alb & $3.5 \mathrm{~g} / \mathrm{dl}$ & $\mathrm{Cl}$ & $101 \mathrm{mEq} / l$ \\
\hline Ch-E & $0.4 \Delta \mathrm{PH}$ & \multicolumn{2}{|l|}{ Tumor maker } \\
\hline ZTT & $18.4 \mathrm{U}$ & CEA & $9.1 \mathrm{ng} / \mathrm{ml}$ \\
\hline TTT & $1.8 \mathrm{U}$ & IAP & $254 \mu \mathrm{g} / \mathrm{ml}$ \\
\hline $\mathrm{T} \cdot \mathrm{Bil}$ & $1.1 \mathrm{mg} / \mathrm{dl}$ & AFP & $1.7 \mathrm{ng} / \mathrm{ml}$ \\
\hline
\end{tabular}

リルビンの軽度上昇, CEA $9.1 \mathrm{ng} / \mathrm{ml}$ 以外特に異常値 を認めない。

下部消化管内視鏡：横行結腸の前回吻合部よりやや 肛門側に潰瘍を認めたが，正面視できず．生検を施行 したが，病理所見では悪性像はみられなかった。

下部消化管造影：吻合部近くに粘膜のひきつれ像を 認めるがその他異常所見を認めず（図了）。

上部消化管内視鏡：胃体中部大彎側後壁よりに巨大 謴瘍の形成を認め，潰場底は深く結腸への穿通が疑わ れた(図4).生検病理では悪性所見は得られなかった。

上部消化管造影：ガストログラフィンにて造影を 行った，上部消化管内視鏡の所見に一致して造影剤の 胃より結腸への流出が確認された（図 5).

1993年10月18日手術施行.

手術所見：正中切開にて開腹.開腹時，腸管と腹壁 との撩着みられたものの，腹水はみられず，肝転移，

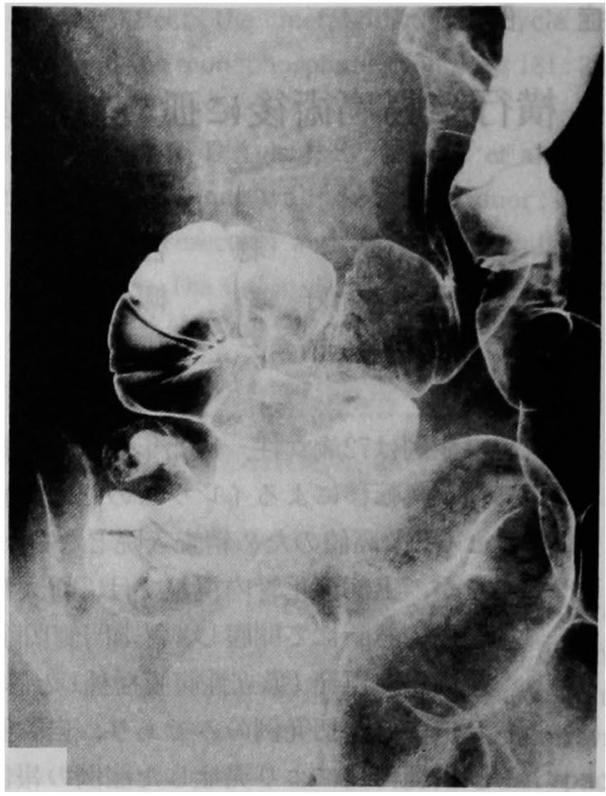

図 3 下部消化管造影：瘦孔は認められず，胃も造影 されていない.

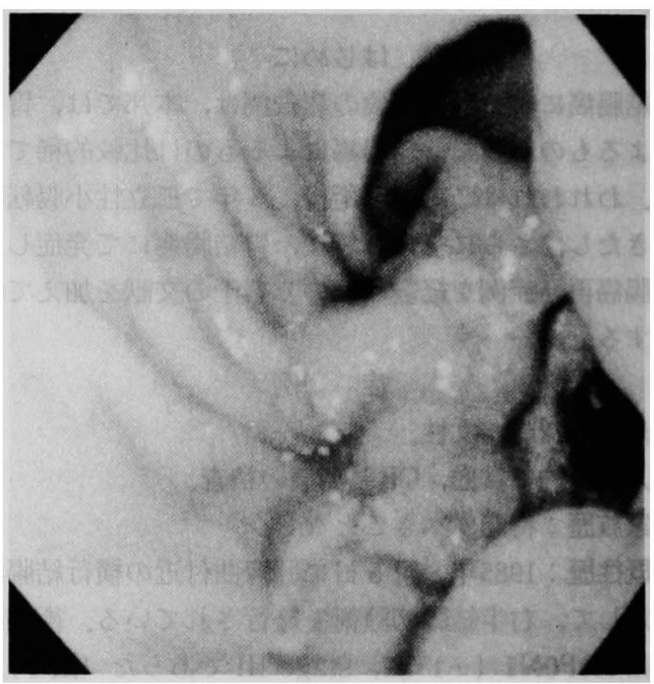

図4 上部消化管内視鏡像：胃体中部大彎後壁よりに 潰瘍を認める．潰場底はかなり深く生検鉗子は容易 に通過した。

腹膜播種もみられず，術前指摘されていた愯孔に向か い周固組織を剝離した. 胃体部を GIAにて切雄. 脾結 腸曲の授動を行い, 口側の回腸と，肛門側の結腸を切 離し，胃・結腸を㿉孔と伴に摘出した。再建は B-I 法, 回腸横行結腸端々吻合を行った。

切除標本：病変は, 周体中部後壁に約 $3 \mathrm{~cm}$ の瘦孔が 


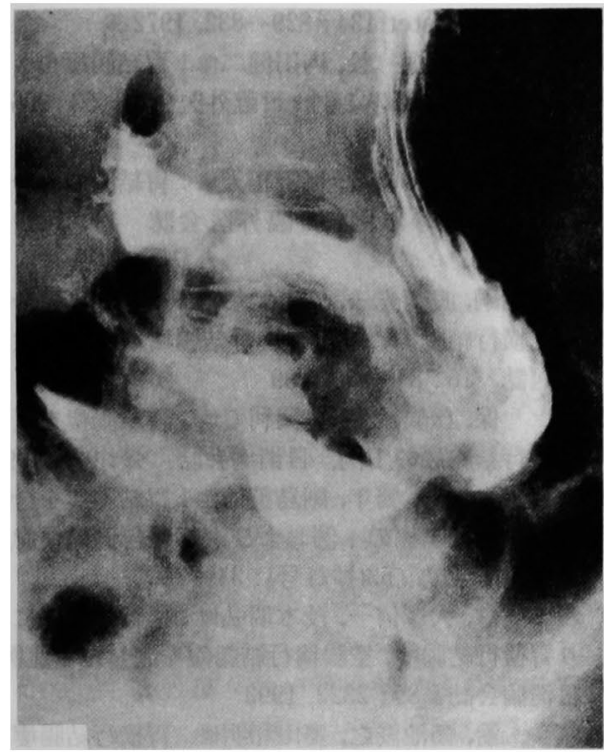

图 5 上部消化管造影所見：ガストログラフィンによ り造影を行った。胃体部より直接横行結腸が造影さ れている.

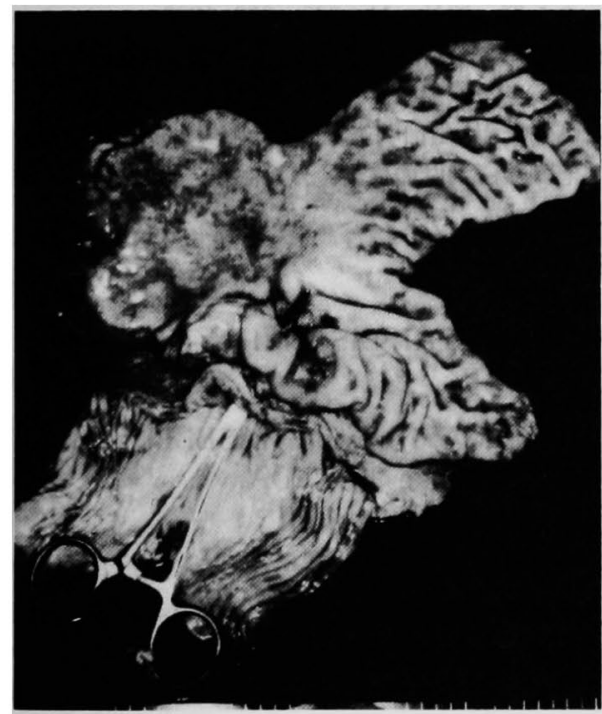

图6今回の切除標本：胃・結腸を㩰孔と伴に一塊と して切除した，瘦孔にはペアン鉗子を通してある。

存在し,結腸側の約 $5 \mathrm{~mm}$ の瘦孔に連続していた(図 6). 病理組織学的所見：胃病変を主体とする中分化型腺 癌であり, 前回の結腸癌, 小腸転移病巣と同じ組織像 でった，又，病変周囲の胃粘膜の萎縮性変化はごく 軽度であった（図７）。

術後経過：術後32日で軽快退院し, 7 力月後の現在,

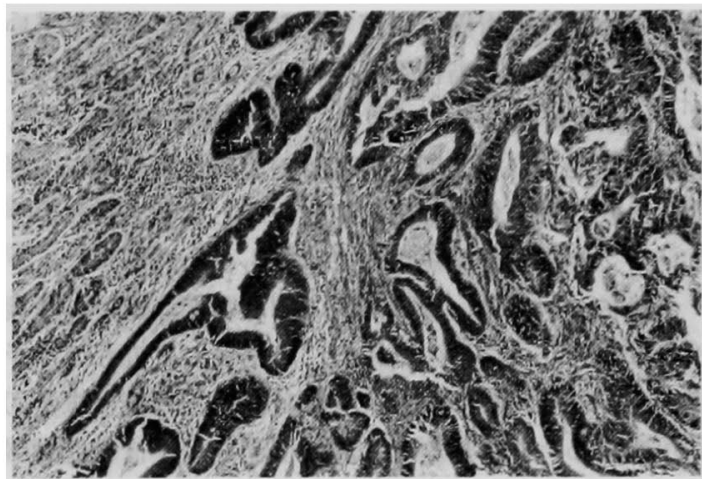

図 7 病理組織所見 (H.E. 染色, $\times 200)$ ：中分化型腺 癌の像であり，癌組織周囲の腸上皮化成はほとんど 認められなかった。

再発を思わせる所見もなく健在である。

\section{考察}

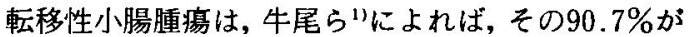
腹部臓器由来であり，そのほとんどが原発巣から小腸 へ連続した浸潤性の転移であった。 また，腺癌におい ては，播種性に小腸壁に浸潤・転移した場合が多く， 槳膜を主体に病変を形成し，粘膜面に向かって浸潤発 育していく，そのため，小腸粘膜は，ひだが長軸方向 に平行し収束したような，ちょうどアコーディオンが 縮まった様な所見を呈する(粘膜の収束像)，今回の症 例も，小腸病巣はちょうどこのような粘膜所見を呈し ており, 孤立性の病変ではあるが, 結腸癌の播種腺癌 細胞が数年を経て,腫瘍を形成したものと考えられる.

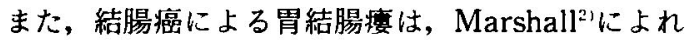
ば，3，200例中10例の0.3\%とまれで，本邦においても 18例の報告) 10)を見るのみである。これらは，いずれ も，限局性に浸潤，発育した腫湯であり，遠隔転移も なく，治学切除可能であった例が多い．Smith ら 胃結腸瘦を合併した結腸癌の特徵として, 腫瘍の組織 学的悪性度は低く, リンパ節転移も軽度な症例が多い と報告している。診断は, 胃 X 線造影検査, 注腸造影 検査により瘦孔が確認されることによるが，一般的に 内圧の加わる注腸造影検査での診断率が高いと言われ ている21-5). しかし，自験例において，注腸造影検查で 異常を認めず，下部消化管内視鏡にても瘦孔の確認は 不可能であった。結腸癌再発による胃結腸瘦は，腫瘍 細胞が播種された部位やその発育形式により異なった 検査所見となることが示唆された。また，その診断は， 上部消化管内視鏡， $\mathrm{X}$ 線造影検査によるが，困難なこ とが多く, 岩崎ら゙)も, 胃内視鏡検査及びその生検では 
Borrmann 2 型胃癌を否定できなかったと報告してい る. 自験例でも, 当初胃癌を否定しきれず, 結局のと ころ, (1)結腸癌の既往があり, 同じ組織像であること, (2)病理所見より腫瘍周囲胃粘膜の萎縮性変化がごく軽 度であり, 胃分化型腺癌の発生母地とは考えにくい"11 という 2 点より結腸癌再発によるものと診断した。

予後については, 胃癌による胃結腸瘻症例が, 予後 不良な報告が多い(2)のに比へ, 結腸癌によるものは予 後の良好な報告例が多く, 本邦18例中, 13例は根治切 除可能であった. 結腸癌他藏器浸潤例の予後が他臓器 合併切除により比較的良好なことから (3)14)胃結腸瘦を 合併した再発結腸癌も，遠隔転移がなければ，積極的 な周囲蔵器及び組織の切除により良好な予後が得られ うると考えられる。

\section{結 語}

結腸癌術後, 小腸に転移をきたし,さらに孤立性腹 膜播種により胃結腸瘦を形成した 1 例を報告し，若干 の文献的考察を加えて報告した。

\section{文献}

1）牛尾恭輔, 石川 勉, 宮川国久他: 転移性小腸腫瘍 のX 線診断. 胃と腸 $27: 793-804,1992$

2) Marshall SF, Kenud-Hansen J : Gastrojejunocolic and gastrocolic fistulas. Ann Surg $145: 770-782,1957$

3) Smith DL, Dockerty MB, Black BM: Gas trocolic fistula of malignant origin. Surg
Gynecol Obstet $134: 829-832,1972$

4）岩崎 茂, 関根 毅, 内田健二他：胃結腸漬をきた した横行結腸癌の 1 例. 日臨外医会誌 $53: 906-$ 910,1992

5）金井道夫, 近藤成彦, 梛野正人他：胃結腸㿋を合併 した結腸癌の 1 例. 日臨外医会誌 48 : 18991902, 1987

6）矢田克嗣, 良河光一, 安芸敏彦他：早期胃癌を合併 した横行結腸癌による胃横行結腸瘦の 1 例. 住友 病医誌 $16: 84-87,1989$

7) 林 保, 松崎武生, 笹岡利安他：胃結腸度を呈し た横行結腸癌の 1 例。日消病会誌 $88: 925,1991$

8）小原長生, 松尾繁年, 副島英伸他：胃結腸瘦を合併 した横行結腸癌の 1 例および本邦報告例の検討。 日臨外医会誌 $53($ 抄録号) : 349, 1992

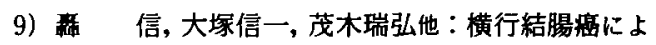
り胃横行結腸瘦, 空腸横行結腸瘦を来した 1 症例。 日消病会誌 $89: 2322,1993$

10）鉄治, 菊池俊之, 奥山和明他：胃横行結腸瘦を 伴う結腸癌の 1 例. 日臨外医会誌 $52: 2496,1991$

11）中村恭一：胃癌の構造 (第 2 版). 医学書院, 東京, 1993, P144-148

12）高松三郎, 堀江良影, 井上典夫他：胃外発育性胃癌 の1例. 消外 $11: 369-373,1988$

13）高橋 孝：新臨床外科全書, 金原出版, 東京, 1979 , p $353-380$

14）高島茂樹, 山口明夫, 喜多一郎他：結腸癌における 他臓器浸潤例の検討. 外科診療 $23: 54-60,1981$

\title{
A GASTROCOLIC FISTULA DUE TO SOLITARY PERITONEAL DISSEMINATION OF TRANSVERSE COLON CANCER
}

\author{
Satoshi KANEKO, Iwao YOSHIZAKI, Nachio AKIYAMA, Hiroyuki HASEBE, \\ Yoshiyuki SAEGUSA, Hironobu YAMAGIE, Yasutaka TAKEDA, \\ Shinsuke MIKAMO, Yuzou FUJII and Masasumi ERIGUCHI \\ Department of Surgery, Institute of Medical Science Hospital, University of Tokyo
}

A case of recurrence of a cancer of the transeverse clon with a gastrocolic fistula is reported. A 72-year-old female was admitted to the our hospital because of anemia $(\mathrm{Hb} 7.9 \mathrm{~g} / \mathrm{dl}$ ) and elevated level of CEA $(9.1 \mathrm{ng} / \mathrm{ml})$ in 1993 . There were previous histories of undergoing hemicolectomy due to a cancer of the transverse colon ( $\mathrm{H} 0 \mathrm{P} 0 \mathrm{~S} 1 \mathrm{~N}(-))$ in 1988 . No lesions were found a colonorectal examination, but an upper GI series revealed a giant ulcer at the greater curvature in the corpus of the stomach penetrating to the transverse colon. A preoperative diagnosis of gastric cancer with a gastrololic fistula was mode a curative operation (colectomy and subtotal gastrectomy) was performed. (H0P0N1S3) Pathological diagnosis was moderately differentiated adenocarcinoma. Histological evidence revealed that is was recurrence of the colonic cancer but not gastric cance. Totally 17 cases of gastrocolic fistula due to primary cancer of the transeverese colon have been reported in Japan. But any report of a gastrocolic fistula due to recurrence of colonic cancer could not be found. 